\title{
THE LESS-INTERRESTED OF ISLAMIC BANK FOR ISSUING SUKUK: Factors and Recommendations
}

\author{
Taufik Awaludin \\ School of Business Bogor Agricultural University \\ e-mail: taufikawaludin98@gmail.com \\ Irfan Syauqi Beik \\ School of Business Bogor Agricultural University \\ e-mail: qibeiktop@gmail.com \\ Rifki Ismal \\ School of Islamic Economics Tazkia, Jakarta \\ e-mail: rifki_ismal@yahoo.com
}

\begin{abstract}
This study attempts to identify dominant factors for banks to issue sukuk and emission features. Applying interviews and Analytic Network Process, this paper Found that the sub-elements which are dominant in influencing IB less interested in issuing sukuk, namely: averse selection/amount cost of fund (management), investment rating companies (investor), the results of using sukuk funds (regulation) and profitability condition (finance). Meanwhile, the sub-elements which are dominant in determining the features of the issuance of sukuk are: macroeconomic condition (emission values), expectations of investors (return)), the contract and the structure of sukuk (collateral), managing mismatch (period), and company liquidity (payment term). The method used in this reseach is the Analytic Network Process (ANP). This study will identify the aspects of emission factors and features.

Penelitian ini bertujuan untuk melakukan identifikasi faktor-faktor dominan dalam persoalan sukuk dan ciri-ciri pengeluarannya. Menerapkan teknik wawancara dan proses jejaring analitis, makalah ini menemukan bahwa sub-sub elemen yang dominan mempengaruhi kurang menariknya IB dalam persoalan sukuk, adalah: menolak seleksi/jumlah pembiayaan (manajemen), rating investasi perusahaan (investor), hasil-hasil penerapan pembiayaan sukuk (regulasi) dan kondisi profitabilitas (keuangan). Sementara itu, sub-sub elemen yang dominan dalam menentukan ciri-ciri pengeluaran sukuk adalah: kondisi makro ekonomi (nilai pengeluaran), ekspektasi dari investor (keuntungan), kontrak dan struktur sukuk (jaminan), pengelolaan yang tidak sebanding (waktu) dan likuiditas perusahaan (syarat-syarat pembayaran). Metode yang digunakan dalam penelitian ini adalah Analytic Network Process (ANP). Penelitian ini akan mengidentifikasi aspek faktor emisi dan fitur. ANP adalah teori matematika dalam pengambilan keputusan yang mampu menganalisis pengaruh melalui asumsi untuk memecahkan berbagai masalah.
\end{abstract}

Keywords: sukuk; islamic banks; issuing; factor; ANP 


\section{A. Preface}

The Indonesian banking system adopts a dual banking systems in which Islamic banks operate alongside conventional banks. Unfortunately, Islamic banks function as the intermediary has not optimal yet. During the years 20112014, the average Financing Deposit Ratio (FDR) Islamic banks stood at $93.98 \%$, while the conventional banking was only $85.37 \%$. However, per December 2015, FDR Islamic banks decreased and only reached 88.03\%.

From the Third Party Fund (TPF), Islamic banks experienced a deposit growth reaching an average of 30.68\% over the period of 2011-2014. Such deposit growth has exceeded the average deposit growth of banking industry which was only reached 14.77\%. However, viewing December 2015, deposit growth of Islamic banks has decreased only $6.11 \%$ (year of year).

Futhermore, Islamic banks have problems particularly the TPF is predominantly a short-term funding. This could be found in the composition of deposits during the years of 2011-2014, in which the average composition of deposits was $59.82 \%$ of the TPF sources received by the bank Observing December 2015, composition of deposit of TPF sources has increased to $60.66 \%$. Therefore, the bank will have difficulty to maintain liquidity and to finance the long-term financing. Hence, as a solution to overcome the problems of the decreasing FDR ratio and the amount of third party funds, there must be anecessity for the bank to have long-term funding sources. In this case, Islamic banks may use capital market instruments for obtaining such a long-term funding source. In fact, Sukuk is an instrument in the Islamic capital markets for corporations needed by Islamic banks to fund their business.

However, during 2015, Bank BNI Syari'ah was the only bank that issued sukuk amounting to Rp. 500 billion. Bank BNI Syari'ah is the seventh corporate banking in issuing sukuk. Prior to the issuance of sukuk by Bank BNI Syari'ah, there were six listed banks that have issued sukuk during the period of 2002 to 2014 namely: Bank Bukopin, Bank Muamalat Indonesia, Bank Syari'ah Mandiri, West Sumatra Regional Development Bank, Sulselbar Regional Development Banks and Bank International Indonesia. In the end of 2015, total accumulated emissions of sukuk by the banks were recorded Rp 3.26 trillion or only amounted to $20.39 \%$ of the total values of the corporate sukuk emissions. 
In deciding to issue sukuk, there are certainly some factors to be considered or determined by Islamic banks. In particular, by using Analytic Network Process (ANP) method, this study identifies dominant factors for banks to issue sukuk and emission features. In the aspect factors will identify the decision of Islamic banks in issuing sukuk related to management, finance, regulation and investor meanwhile the aspect features will identify the decision of Islamic banks in determining the features of emission values, periods of sukuk, the return of income for investors, collateral and terms of payment. Results of the study of sukuk issuance are expected to provide recommendations for managerial implications, particularly for Islamic banks to issue sukuk as well as advicing regulators to increase the issuance of sukuk instruments.

The method used in this reseach is the Analytic Network Process (ANP). This study will identify the aspects of emission factors and features. ANP is a mathematical theory in decision-making that is able to analyze the influence through assumptions to solve various problems. This method is used in the form of a settlement with the consideration of the adjustment of the complexity of the problem of decomposition of the synthesis with the priorities that produces the effect of greatest priority. ANP is also able to explain the model factors dependence and its feedback systematically. Decision-making in the application of ANP is proceeded by performing the above considerations and validation of empirical experience and level of expertise of the respondents. This method makes it possible to identify, classify and collate all the factors affecting the outputs or the resulting decisions. ${ }^{1}$

In this study, the data used is primary and secondary data. The primary data sourced from interviews (depth interview) with three (3) Islamic bank's practitioner who has an understanding of the issues discussed. As for the secondary data obtained from the literature books, journals, dissertations and reports publications regulators are closely related to the issue sukuk and Islamic banking.

${ }^{1}$ Saaty TL, Vargas LG., Decision Making with the Analytic Network Process. Economic, Political, Social and Technological Applications with Benefits, Opportunities, Costs and Risks (New York (US): Springer Science and Business Media), 2013. 
Selection of respondents in this study was conducted by purposive sampling and convenience sampling. The sampling is included in the non-probability sampling techniques. ${ }^{2}$ Respondents being chosen are those practitioners who have the knowledge to answer questions and get an insight into the theoretical research. ${ }^{3}$ The total number of respondents in the study are 3 (three) practitioners IB which have not been issuing sukuk (classified as B1, B2 and B3).

There are some stages of this research. Phase 1 is the construction of models of ANP Compiled based on literature review of theoretical and empirical and provide questions to the experts and practitioners of sukuk as well as through in-depth interview to assess more fully the information to obtain the real issues.

Phase 2 is the quantification models. Using the questions in the questionnaire ANP in the form of pairwise comparison (benchmarking partner) between elements in the cluster to determine which of the two bigger influence (more dominant) and how big the difference through a numerical scale of 1-9. Data assessment results are then collected and inputted through a super decision software to be processed so as to produce output in the form of priority and supermatriks. Results from each respondent will be inputted on a network separate ANP.4 The following numerical scale based on Saaty and Vargas: ${ }^{5}$

Table 1.

The Fundamental Scale of Absolute Numbers

\begin{tabular}{cl}
\hline $\begin{array}{c}\text { Intensity of } \\
\text { Importance }\end{array}$ & \multicolumn{1}{c}{ Definition } \\
\hline 1 & Equal Importance \\
2 & Weak \\
3 & Moderate Importance \\
4 & Moderate Plus \\
5 & Strong Importance
\end{tabular}

\footnotetext{
2Sekaran U., "Research Method for Business: a Skill Building Approach", Journal of Education for Business. 68(5), 2003., pp. 316-317.

${ }^{3}$ Saunders et al, Research Methods For Business Students, 5th edition (England: Pearson Education Limited), 2009.

${ }^{4}$ Ascarya., "The Persistence of Low Profit and Loss Sharing Financing in Islamic Banking: "the Case of Indonesia", Review of Indonesian Economic and Business Studies. Vol. 1, 2011.

${ }^{5}$ Saaty and Vargas, Decision Making with the Analytic ...
} 


\begin{tabular}{cc}
6 & Strong Plus \\
7 & Very Strong or Demonstrated Importance \\
8 & Very, Very Strong \\
9 & Extreme Importance \\
\hline
\end{tabular}

Phase 3 is the Synthesis and Analysis. Synthesis and analysis of the results is based on the geometric mean (GM) and rater agreement. Geometric Mean is the result of an opinion on the group so as to form a consensus while rater agreement is a measure that indicates the level of conformity (approval) of the respondents (R1-Rn) to a problem in one cluster. The instrument used to measure rater agreement was Kendall's Coefficient of Concordance (W; $0<W \leq$ 1). $W=1$ indicates a perfect fit. ${ }^{6}$

\section{B. Sukuk Issuence and Requirement}

According to the Financial Services Authority Regulation No. 18/P0JK. 04/ 2015 on Sukuk issuance and requirements, the definition of sukuk are Islamic securities in the form of a certificate or proof of ownership of equal value and represent an integral part or not split (syuyu', undivided share) of the underlying asset.

Zin et al.,7 sukuk could be structured along with different techniques, while conventional bond is a promise to repay the loan, the sukuk is a partial ownership in debt (murabaha sukuk), assets (al-Ijära sukuk), project (al-Istishna sukuk), business (al-musharaka sukuk) or investment (al-istithmar sukuk). Sukuk structures are diverse, not found in the Qur'an and the Sunna, but is the result of ijtihad-based context developed by scholars and thinkers. ${ }^{8}$

Wahid said, elements or features of sukuk hadsimilliaritywith the conventional bonds. The elements on the issuance of sukuk were: emission values, period, return, terms of payment and the collateral as an underlying asset

\footnotetext{
${ }^{6}$ Ascarya \& Yumanita D., "The Development of Islamic Financial System in Indonesia and the Way Forward”, Working Paper No. WP/10/04, 2010.

7Zin et al., "The Effectiveness of Sukuk in Islamic Finance Market", Australian Journal of Basic and Applied Sciences., 5 (12), . 2011, pp. 472-478.

8Saeed A, Salah O., Development of sukuk: pragmatic and idealist approaches to sukuk structures. Journal of International Banking Law and Regulation, 2013, 1 (1), pp. 41-52.
} 
of sukuk issuance. Sukuk issuance will provide benefits for the company. ${ }^{9}$ Usman, the benefits of sukuk were: 1) Sukuk is one of the best ways to finance large enterprises. 2) Sukuk provide an ideal means for investors who want to spread the flow of capital and in need of funds. 3) Sukuk is the best way to manage the liquidity for banks and Islamic Financial Institutions. 4) Sukuk is a tool for equitable distribution of wealth because they enable allinvestors to profit.10

Several previous studies suggested some benefits associated with sukuk and factors relating to the issuance of sukuk, including:

Bapepam-LK in 200911 revealed that external factors are the dominant factors affecting the Issuer/Issuer Sukuk Company in issuing sukuk followed by regulatory factors and internal factors. The dominant external factor is the existence of excess liquidity in the market (market liquidity) and the market interest rate, while the dominant factor influencing legislation is the provision that the assets / operations underlying the issuance of sukuk are not contrary to Islamic principles and tax treatment on the sukuk. The internal factors are the dominant influence is the issuance of sukuk do when the Islamic finance industry is growing rapidly and the issuance of sukuk is complementary of the issuance of conventional bonds. The cost factor for Issuers / PP Sukuk based on the results of the study showed that the cost factor sukuk is not more expensive than the cost of issuing bonds. The most substantial costs in issuing sukuk is the cost incurred for appraisal services.

Dewi $^{12}$ concluded that the problems in an effort to improve the overall development of corporate sukuk described, then generate a sequence of priority: 1) a lack of understanding (the issuer); 2) The secondary market is less liquid (market); 3) lack of knowledge (investor); 4) incentives (support), whereas the

\footnotetext{
${ }^{9}$ Wahid NA., Memahami dan Membedah Obligasi pada Perbankan Syariah (Yogyakarta (id): Ar-Ruzz Media), 2010.

10Usmani MT, "Sukuk and Their Contemporary Applications.", Paper inAAOIFI Shari’a Council Meeting: Saudi Arabia, 2007.

${ }^{11}$ Badan Pengawas Pasar Modal dan Lembaga Keuangan (BAPEPAM-LK), Faktor-faktor yang Mempengaruhi Minat Emiten di Pasar Modal. Laporan Kajian Minat Emiten (Jakarta (id): BAPEPAM-LK, 2009).

${ }^{12}$ Dewi N., "Mengurai Masalah Pengembangan Sukuk Korporasi di Indonesia Menggunakan Analytic Network Process", Jurnal Islamic Finance \& Business Review., Vol. 6 No. 2, 2011, pp. 138-167.
} 
priority solution capable of resolving the problems consist of: 1) intensive socialization; 2) encouragement of SOEs; 3) improvement of tax regulations; 4) product innovation; 5) incentives. The problem based aspect of the results showed that the dominant aspect is the Issuer and Support. The dominant factor in the problem is a lack of understanding of the issuer Issuer and the company's commitment to use sukuk as an alternative major long term funding source.

Abdo revealed that there were several issues related to the issuance of sukuk, which needed a secondary market, yields look at the benchmark market, standardizing on contract and sukuk scheme, the availability of tangible assets and the quality of regulation related to the issuance of sukuk. ${ }^{13}$

Shahar et al., ${ }^{14}$ found that compared with factors of corporate governance, namely the characteristics of the company's stock price has more prominent role in explaining the choice between Islam debt and conventional debt. This shows that only borrowers who have low back hope will appeal to the sukuk to minimize their losses in the event of failure because of sukuk mainly based on profit and loss sharing financing scheme. Meanwhile, issuers are having, the expected high interest-based financing (conventional debt) is preferred in order to maximize profits. In relation to the characteristics of corporate governance, only the size of management and public ownership affects sukuk issuanced. This indicates that the code of corporate governance has been a particular dibatas influence of corporate financing options.

\section{Results}

In issuing sukuk, Islamic banks management beforehand attention to a number of factors that influence their decision-making in issuing sukuk. Based on the results, the priority of each of the respondents associated the dominant factor for Islamic banks in deciding the issue sukuk as shown in Appendix 3. These data when depicted in graphic form are as follows:

\footnotetext{
${ }^{13}$ A. Abdo, "A Critical Review of the Sukuk Market Aqualitative Study to Identify Current Risks and Opportunities", Dissertation (Dublin: Dublin Business School, 2014).

${ }^{14}$ Shahar et.al., "Firms' Issuing Choice Between Islamic and Conventional Debt: Does Corporate Governance Structure Matter?" Prosiding Persidangan Kebangsaan Ekonomi Malaysia ke-9; 2014 Oktober 17-19; Kuala Terengganu, Malaysia. Universiti Utara Malaysia, 2014.
} 


\section{Aspect Factors}

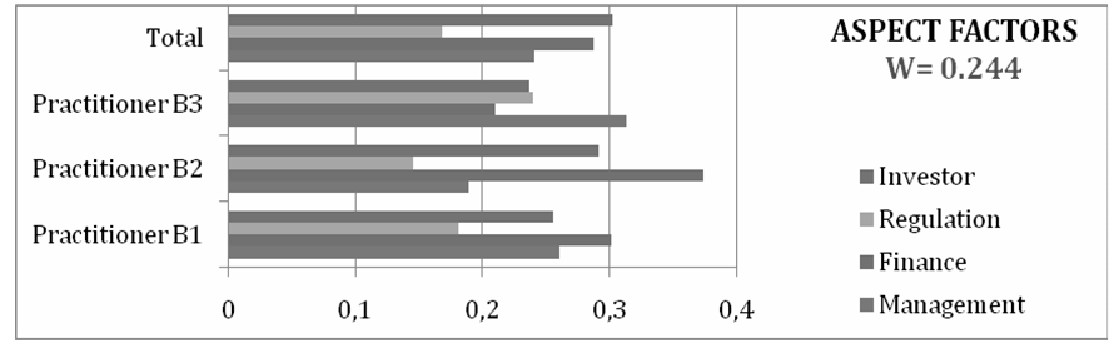

Figure 1. Proririty of Aspect Factors

In Figure 1, seen in aspect factors clusters, according to practitionerB3 that the most dominant elements into consideration in deciding to issue sukuk are management. Meanwhile, the practitioner B1 and B2have same opinion that the dominant element into consideration in deciding the issue sukuk are finance. Overall, all respondents found that the dominant factor in deciding to issue sukuk IB is a factor investors followed by the finance factor with lowrater agreement values $(\mathrm{W}=0.244)$. It can be concluded that the investor and finance factorare the dominant element of the IB to issue sukuk. If the IB will decide to issue sukuk, the dominant consideration IB are investors and finance factors.

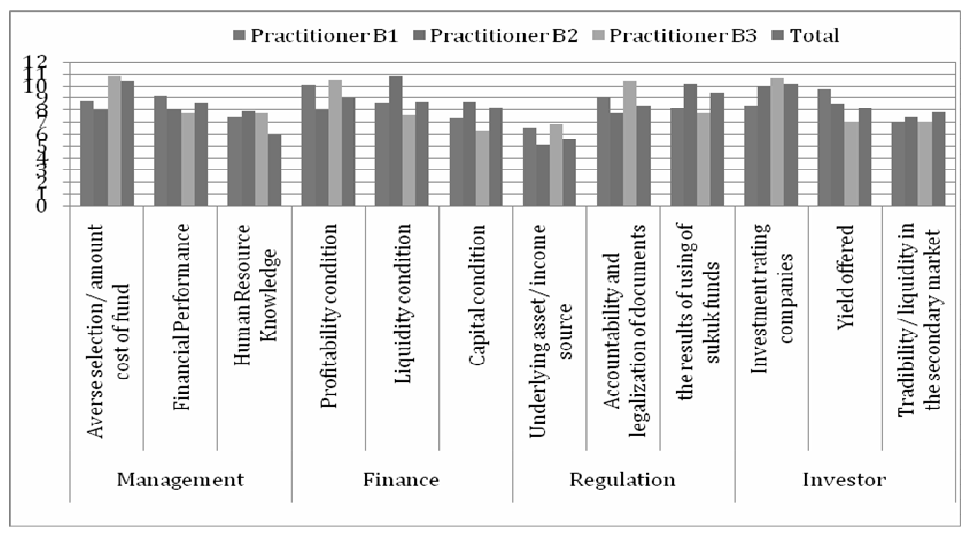

Figure 2.

Description Priority on Aspect Factors 
In the chart above we can conclude that practitioner B1 has an opinion that profitability condition (finance factor) is the dominat sub-element in factors aspect for IB in deciding to issue sukuk. Percentage of profitability condition by practitioner B1 amounting to $10.08 \%$. As according to respondent practitioner B2 has an opinion that liquidity condition (finance factor) with a percentage of $10.83 \%$ is the dominant sub-element of aspectfactors for consideration by IB in deciding to issue sukuk. Meanwhile, practitioner B3 has an opinion that averse selection/amount the cost of funds (management factor) with a percentage of $10.80 \%$ is the dominant sub-element of aspect factors for consideration by IB in deciding to issue sukuk

Overall, all respondents believe that the averse selection/amount the cost of funds (management factor) is a dominant sub-element in aspect factors for IB in deciding to issue sukuk with a percentage of $10.34 \%$. Thus, the combination of factors that determing IB in deciding to issue sukuk, namely: averse selection/amount cost of fund (management), investment rating companies (investor), the results of using sukuk funds (regulation) and profitability condition (finance). By this it can be concluded that the IB in deciding to issue sukuk, firstly pay attention to internal factors, namely management, followed by external factors, namely investor.

\section{Aspect Features}

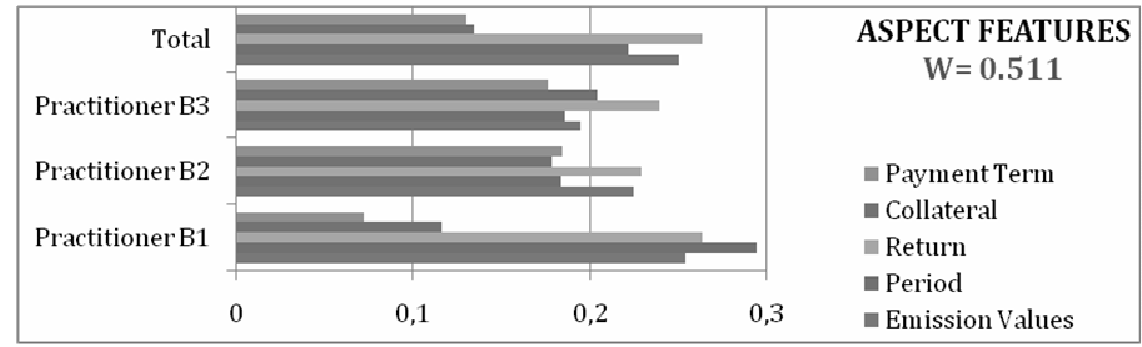

Figure 3.

Priority of Aspect Features

In Figure 3, seen in the clusteraspect features, according topractitioner B2 and B3 have the same opinion that the dominant element into consideration in 
determining the features of the issuance of sukuk is a returnfeature. Meanwhile, according to practitioner B1 that the dominant element into consideration in determining the features of the issuance of sukuk is a periodefeature. Overall all respondents found that the dominant feature for IB in sukuk issuance is return features followed by emission values features with high rater agrrement values $(\mathrm{W}=0.511)$. It can be concluded that the return and the emission values is the dominant element by IB as a feature on the issuance of sukuk. If the IB will decide to issue sukuk, IB dominant consider the return features and the emissions values.

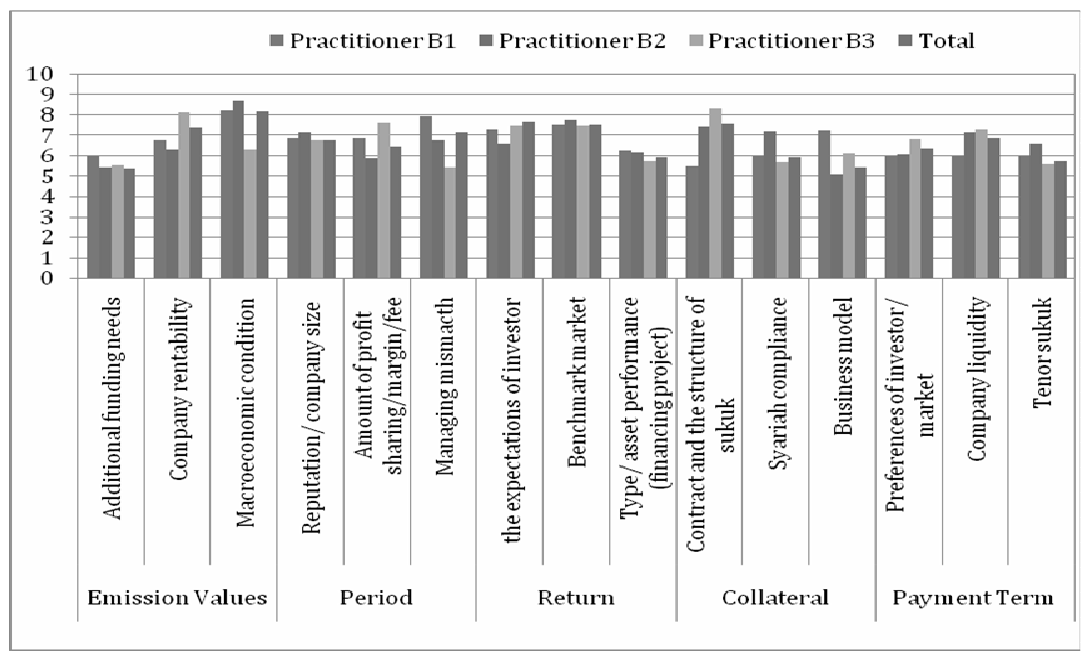

Figure 4.

Description Priority on Aspect Features

In the chart above we can conclude that practitioner B1 and B2 have same opinion that the macroeconomic condition (emission values feature) is the dominat sub-elementas a feature in determining the issuance of sukuk, amounting $8.71 \%$ and $8.11 \%$ while according practitioner B3 found that the dominat sub-element is the contract and the structure of sukuk (collateral feature) by $8.29 \%$.

Overall, all respondents believe that the macroeconomic condition (emission values feature) is a sub-element which isdominant in a feature on the 
issuance of sukuk with a percentage of $8.13 \%$. Thus, the combination of factors that determiningof the features of the issuance of sukuk namely are: the macroeconomic condition (emission values), the expectations of investors (return), the contract and the structure of sukuk (collateral), managing mismatch (period) and the company liquidity (payment terms). By this, it can be concluded that mostly IB in determining the features of the issuance of sukuk, first pay attention to the emission values feature and followed with return feature.

Briefly Figure 5, shows the results related to a combination of factors that affect the overall Islamic banks in deciding issuing sukuk:

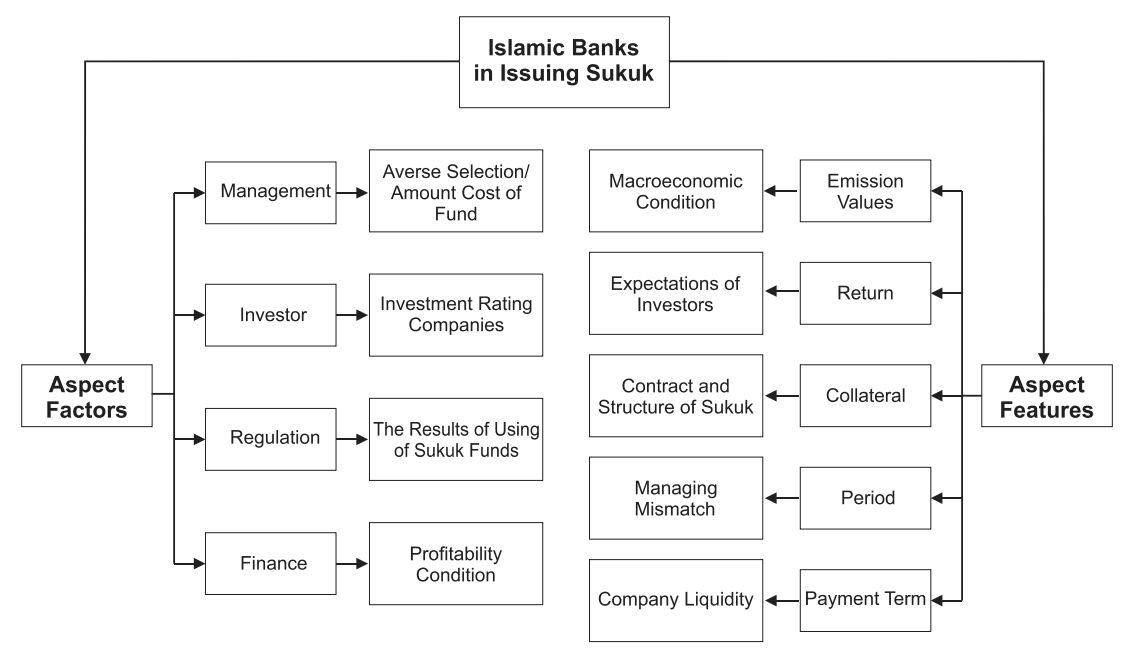

Figure 5.

Results Combined Overall Factors Affecting Mostly Islamic Banks in Deciding Issuing Sukuk

\section{Conclusions}

Based on this research, it is concluded that: 1) The dominant factor determiningmostly Islamic banks in deciding to issue sukuk, namely management factorsfollowed by investor factors. Thus as a combination, sub-elements of the dominant influence in deciding IB to issue sukuknamely: averse selection/amount cost of fund (management), investment rating companies 
(investors), the results of using sukuk funds (regulation) and profitability condition (finance). 2) In sukuk issuance, the dominant feature a consideration for Islamic banks is emission value features then followed by thereturn feature. Thus, the combination of sub-elements were dominant for IB in determining the features of the issuance of sukuk namely: the macroeconomic condition (emission values), the expectations of investors (return), the contract and the structure of sukuk (collateral), managing mismatch (period) and the company liquidity (payment terms).

This study is a preliminary study that seeks to identify the factors that influence IB in deciding to issue sukuk. The object of this study is Islamic banks that have not issuing sukuk in Indonesia. The advice that can be given for Islamic banks is as for the IB, the cost of the most expensive is the cost of capital over the source TPF obtained. It can be done by IB by increasing the portfolio of resources in savings and current accounts among individuals who have a big budget (High Net Worth Individual) and among government agencies. Bank can also increase the hajj funding source in cooperation with Umrah and Hajj travel companies. Furthermore, banks should be able to improve the performance of the company in order to obtain a good investment rating companies.

Beside that, banks must maintain the efficiency and increase the productive financing to get good profits for the company. For the regulator, to increase emissions sukuk Islamic banks there are some things that can be done by the regulators that provide incentives to reduce taxes and the emission cost. Beside that, regulator must be conduct intensive socialization related procedures and relevant provisions of the Islamic capital market. [w] 


\section{BIBLIOGRAPHY}

Abdo A., "A Critical Review of the Sukuk Market: A Qualitative Study to Identify Current Risks and Opportunities", [dissertation], Dublin: Dublin Business School, 2014.

Ascarya, Yumanita D., "The Development of Islamic Financial System in Indonesia and the Way Forward", Working Paper No. WP/10/04, 2010.

Ascarya, "The persistence of low profit and loss sharing financing in islamic banking: "the case of Indonesia". Review of Indonesian Economic and Business Studies, Vol. 1, 2011.

Awaludin F, Masih M., "Sukuk Pricing Dynamics -Factors Influencing Yield Curve of the Malaysian Sukuk", MPRA Paper, No. 66355, 2015, pp. 1-23.

Baitenova N, Zamanbekov D., "Opportunities Related to Securitization and Sukuk Structure of Shariah Compliant Securitization", Middle-East Journal of Scientific Research, Vol. 15, No. 6, 2013, pp. 862-868.

Badan Pengawas Pasar Modal dan Lembaga Keuangan[BAPEPAM-LK], Peraturan No. IX. A. 13 Tahun 2009 tentang Penerbitan Efek Syari'ah, Jakarta: BAPEPAM-LK, 2009.

Badan Pengawas Pasar Modal dan Lembaga Keuangan[BAPEPAM-LK], "Faktorfaktor yang Mempengaruhi Minat Emiten di Pasar Modal”, Laporan Kajian Minat Emiten, Jakarta: BAPEPAM-LK, 2009.

Badan Pengawas Pasar Modal dan Lembaga Keuangan[BAPEPAM-LK], Peraturan No. IX. A. 14 Tahun 2012 tentang Akad-akad yang digunakan dalam Penerbitan Efek Syari'ah di Pasar Modal, Jakarta: BAPEPAM-LK, 2012.

Dewi N., "Mengurai Masalah Pengembangan Sukuk Korporasi di Indonesia Menggunakan Analytic Network Process", Jurnal Islamic Finance \& Business Review. Vol. 6, No. 2, 2011, pp. 138-167.

Diaw A, Bacha OI, Lahsasna A., "Incentive-compatible Sukuk Musharakah for Private Sector Funding', International Journal of Islamic Finance, Vol. 4, No. 1, 2013, pp. 39-80. 
Dewan Syariah Nasional Majelis Ulama Indonesia [DSN MUI], Fatwa No. 20 Tahun 2001 tentang Pedoman Pelaksanaan Investasi untuk Reksa Dana Syari'ah, Jakarta: DSN MUI, 2001.

Dewan Syari'ah Nasional Majelis Ulama Indonesia [DSN MUI], Fatwa No. 32 Tahun 2002 tentang Obligasi Syari'ah, Jakarta: DSN MUI, 2002.

Dewan Syari'ah Nasional Majelis Ulama Indonesia [DSN MUI], Fatwa No. 33 Tahun 2002 tentang Obligasi Syari'ah Mudharabah, Jakarta: DSN MUI, 2002.

Dewan Syariah Nasional Majelis Ulama Indonesia [DSN MUI], Fatwa No. 40 Tahun 2003 tentang Pasar Modal dan Pedoman Umum Penerapan Prinsip Syari'ah di Bidang Pasar Modal, Jakarta: DSN MUI, 2003.

Dewan Syari'ah Nasional Majelis Ulama Indonesia [DSN MUI], Fatwa No. 41 Tahun 2004 tentang Obligasi Syari'ah Ijarah, Jakarta: DSN MUI, 2004.

Dewan Syari'ah Nasional Majelis Ulama Indonesia [DSN MUI], Fatwa No. 59 Tahun 2007 tentang Obligasi Syari'ah Mudharabah Konversi, Jakarta: DSN MUI, 2007.

Dewan Syari'ah Nasional Majelis Ulama Indonesia [DSN MUI], Fatwa No. 71 Tahun 2008 tentang Sale and Lease Back, Jakarta: DSN MUI, 2008.

Dewan Syari'ah Nasional Majelis Ulama Indonesia [DSN MUI], Fatwa No. 80 Tahun 2011 tentang Penerapan Prinsip Syari'ah dalam Mekanisme Perdagangan Efek Bersifat Ekuitas di Pasar Reguler Bursa Efek, Jakarta: DSN MUI, 2011.

Elshazly MR, Tripathy P., "Sukuk Structures, Profiles and Risks", Paper of Columbia College, 2013, pp. 1-18.

Jobst A, Kunzel P, Mills PS, Amadou SY., "Islamic Bond Issuance -What Sovereign Debt Managers Need to Know", International Journal of Islamic and Middle Eastern Finance and Management. Vol. 1 No. 4, 2008., pp. 330-344 .

Nagano M. 2010. "Islamic Finance and the Theory of Capital Structure", MPRA Paper. No. 24567, pp.1-17.

Oh I, Lee JD, Hwang S, Heshmati A., Analysis of product efficiency in the Korean automobile market from a consumer's perspective. Empirical Economics, Vol. 38, No. 1, 2009, pp. 119-137.

Otoritas Jasa Keuangan (OJK), Peraturan Otoritas Jasa Keuangan No. 15 tahun 2015 tentang penerapan prinsip syari'ah di pasar modal, Jakarta: OJK, 2015. 
Otoritas Jasa Keuangan (OJK), Peraturan Otoritas Jasa Keuangan No. 16 tahun 2015 tentang ahli syari' ah pasar modal, Jakarta: OJK, 2015.

Otoritas Jasa Keuangan (OJK), Peraturan Otoritas Jasa Keuangan No. 18 tahun 2015 tentang Penerbitan dan Persyaratan Sukuk, Jakarta: OJK, 2015.

Otoritas Jasa Keuangan (OJK), Laporan Publikasi Statistik Pasar Modal Syari'ah, Jakarta: OJK, 2015.

Otoritas Jasa Keuangan (OJK), Laporan Publikasi Statistik Perbankan Syari'ah, Jakarta: OJK, 2015.

Paltrinieri A, Dreassi A, Miani S, Sclip A., "In Search of Zero Beta Assets: Evidence from the Sukuk Market", International Journal of Social, Behavioral, Educational, Economic and Management Engineering. Vol. 9, No. 1, 2015., pp. 67-75.

Rezaei Z., "Sukuk: an Islamic Financial Instrument", Management and Administrative Sciences Review, Vol. 2. No. 3, 2013, pp. 261-267.

Saaty TL, Vargas LG., Decision Making with the Analytic Network Process. Economic, Political, Social and Technological Applications with Benefits, Opportunities, Costs and Risks, New York: Springer Science and Business Media, 2013.

Saaty TL., Theory and Applications of the Analytic Network Process: Decision Makingwith Benefits, Opportunities, Costs and Risks, Pittsburgh: RWS Publications, 2005.

Saeed A, Salah 0., "Development of Sukuk: Pragmatic and Idealist Approaches to Sukuk Structures", Journal of International Banking Law and Regulation, Vol. 1, No. 1, 2013, pp. 41-52.

Said A, Grassa R., The Determinants of Sukuk Market Development: Does Macroeconomic Factors Influence the Construction of Certain Stucture of Sukuk?" Journal of Applied Finance \& Banking, Vol. 3, No. 5, 2013, pp. 251267.

Said A., "Does the Use of Sukuk (Islamic Bonds) Impact Islamic Banks Performances? A Case Study of Relative Performance during 2007-2009", Middle Eastern Finance and Economics, Vol. 12, 2011, pp. 65-76.

Saunders M, Lewis P, Thornhill A., Research Methods For Business Students, 5-th ed., England: Pearson Education Limited, 2009. 
Sekaran U., "Research Method for Business: a Skill Building Approach", Journal of Education for Business, Vol. 68, No. 5, 2003, pp. 316-317.

Shahar HBK, Ibrahim Y, Mohd KMT., "Firms' Issuing Choice between Islamic and Conventional Debt: Does Corporate Governance Structure Matter?" 9th Prosiding Persidangan Kebangsaan Ekonomi Malaysia, , 2014 Oktober 17-19-th; Kuala Terengganu: Universiti Utara Malaysia.

Shaikh SA., "Financing Public Infrastructure Using Sovereign Sukuk", Journal of Islamic Banking and Finance, Vol. 32, No. 1, 2015, pp. 11-22.

Siswantoro D., "Analysis of the first ijarah sukuk default in Indonesia: how could it be?" International Journal of Islamic Banking \& Finance, Vol. 3, No. 2, 2013., pp. 1-15.

Tariq AA, Dar H., "Risks of Sukuk Structures: Implication for Resource Mobilization", Thunderbird International Business Review, Vol. 49, No. 2, 2007, pp. 203-223

Undang-undang Republik Indonesia No. 19 Tahun 2008 tentang Surat Berharga Syari'ah Negara.

Undang-undang Republik Indonesia No. 21 Tahun 2008 tentang Perbankan Syari'ah.

Usmani MT., "Sukuk and Their Contemporary Applications", paper in AAOIFI Shari'a Council Meeting, Saudi Arabia , 2007.

Wahid NA. Memahami dan Membedah Obligasi pada Perbankan Syari'ah. Yogyakarta: Ar-Ruzz Media, 2010.

Zaheer S, Wijnbergen SV., "Sukuk Defaults: on Distress Resolution in Islamic Finance', Tinbergen Institute Discussion Paper. No. 13-087/VI/ DSF57, 2013, pp. 1-51.

Zakaria NB, Isa MAM, Abidin RAZ., Sukuk rating, default risk and earnings response coefficient. Advances in Natural and Applied Sciences, Vol. 7, No. 2, 2013, pp. 131-137.

Zin MZM, Sakat AA, Ahmad NA, Nor MRM, Bhari A, Ishak S, Jamain MS., The Effectiveness of Sukuk in Islamic Finance Market", Australian Journal of Basic and Applied Sciences, Vol. 5, No. 12, 2011, pp. 472-478. 


\section{Appendix 1. \\ Definition and Reference of the Sub-element on Aspect Factors}

\begin{tabular}{|c|c|c|}
\hline Element & Sub_element & Definition and Reference \\
\hline \multirow{6}{*}{ 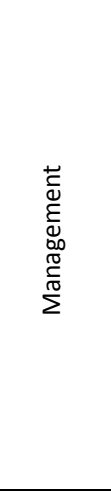 } & \multirow{2}{*}{$\begin{array}{l}\text { Averse selection/ } \\
\text { amount the cost } \\
\text { of fund }\end{array}$} & $\begin{array}{l}\text { IB's references for selecting the source of funding capital costs } \\
\text { on companies }\end{array}$ \\
\hline & & BAPEPAM-LK (2009); Shahar et al. (2014) \\
\hline & \multirow{2}{*}{$\begin{array}{l}\text { Financial } \\
\text { Performance }\end{array}$} & $\begin{array}{l}\text { The company's overall financial condition shown in the annual } \\
\text { financial statements }\end{array}$ \\
\hline & & $\begin{array}{l}\text { Baitenova andZamanbekov (2013); Elshazly and Tripathy } \\
\text { (2013); Shahar et al. (2014) }\end{array}$ \\
\hline & \multirow{2}{*}{$\begin{array}{l}\text { Human Resource } \\
\text { Knowledge }\end{array}$} & $\begin{array}{l}\text { The availability of human resource in companies that have } \\
\text { relevant knowledge of the Islamic Capital Market }\end{array}$ \\
\hline & & $\begin{array}{l}\text { Nagano (2010); Dewi (2011); BAPEPAM-LK (2012); POJK } \\
(2015)\end{array}$ \\
\hline \multirow{6}{*}{ 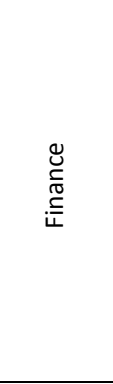 } & \multirow[t]{2}{*}{$\begin{array}{l}\text { Profitability } \\
\text { condition }\end{array}$} & $\begin{array}{l}\text { The company's ability to generate earnings and demonstrates } \\
\text { the company's business performance }\end{array}$ \\
\hline & & Said (2011) \\
\hline & \multirow[t]{2}{*}{$\begin{array}{l}\text { Liquidity } \\
\text { condition }\end{array}$} & $\begin{array}{l}\text { Liquidty position related to the comparison between the TPF } \\
\text { source of financing distributed }\end{array}$ \\
\hline & & Said (2011); Baitenova and Zamanbekov (2013); Shaikh (2015) \\
\hline & \multirow[t]{2}{*}{ Capital Condition } & $\begin{array}{l}\text { The Position of the capital adequacy ratio (CAR), which } \\
\text { occurred in the company }\end{array}$ \\
\hline & & Baitenova and Zamanbekov (2013) \\
\hline \multirow{6}{*}{ 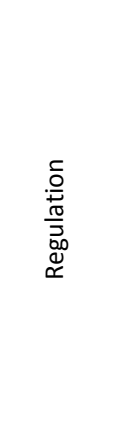 } & \multirow{2}{*}{$\begin{array}{l}\text { Underlying asset/ } \\
\text { income source }\end{array}$} & $\begin{array}{l}\text { Availibility of asset/ income source underlying the issuance of } \\
\text { sukuk }\end{array}$ \\
\hline & & BAPEPAM-LK (2009); Abdo (2014); Shaikh (2015); POJK ( 2015) \\
\hline & \multirow{2}{*}{$\begin{array}{l}\text { Accountability } \\
\text { and legalization of } \\
\text { documents }\end{array}$} & $\begin{array}{l}\text { The readiness of the company to comply with the } \\
\text { transparency of data and related documents }\end{array}$ \\
\hline & & BAPEPAM-LK (2009); POJK (2015) \\
\hline & \multirow{2}{*}{$\begin{array}{l}\text { the results of } \\
\text { using of Sukuk } \\
\text { funds }\end{array}$} & $\begin{array}{l}\text { The willingness and ability of companies to use the proceeds } \\
\text { of the sukuk in accordance with the purpose of publishing }\end{array}$ \\
\hline & & POJK (2015) \\
\hline \multirow{3}{*}{ 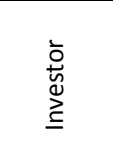 } & \multirow{2}{*}{$\begin{array}{l}\text { Investment Rating } \\
\text { company }\end{array}$} & Position investment rating held by the company \\
\hline & & $\begin{array}{l}\text { Baitenova and Zamanbekov (2013); Siswantoro (2013); } \\
\text { Zakaria et al. (2013) }\end{array}$ \\
\hline & Yield offered & The company's ability to offer attractive yields for investors \\
\hline
\end{tabular}




\begin{tabular}{|l|l|l|}
\hline & $\begin{array}{l}\text { BAPEPAM-LK (2009); Elshazly and Tripathy (2013); Abdo } \\
\text { (2014); Shahar et al. (2014) }\end{array}$ \\
\cline { 2 - 3 } & $\begin{array}{c}\text { Tradibility/ } \\
\text { liquidity in the } \\
\text { secondary market }\end{array}$ & $\begin{array}{l}\text { Ability of the sukuk issued by companies rated tradable in the } \\
\text { secondary market by investors }\end{array}$ \\
\cline { 3 - 3 } & BAPEPAM-LK (2009); Abdo (2014) \\
\hline
\end{tabular}

Appendix 2.

\section{Definition and Reference of the Sub-element on Aspect Features}

\begin{tabular}{|c|c|c|}
\hline Element & Sub_element & Definition and Reference \\
\hline \multirow{6}{*}{ 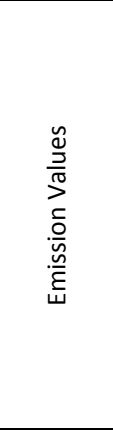 } & \multirow{2}{*}{$\begin{array}{l}\text { Additional funding } \\
\text { needs }\end{array}$} & The amount of additional funding needs for companies \\
\hline & & $\begin{array}{l}\text { Usmani (2007); Nagano (2010); Said (2011); Elshazly and } \\
\text { Tripathy (2013); Rezaei (2013); Abdo (2014) }\end{array}$ \\
\hline & \multirow{2}{*}{ Company rentability } & $\begin{array}{l}\text { The company's ability to pay back the fund investor at } \\
\text { maturity of sukuk }\end{array}$ \\
\hline & & $\begin{array}{l}\text { Siswantoro (2013); Zaheer and Wijnbergen (2013); } \\
\text { Shahar et al. (2014) }\end{array}$ \\
\hline & \multirow{2}{*}{$\begin{array}{l}\text { Macroeconomic } \\
\text { condition }\end{array}$} & $\begin{array}{l}\text { Conditions of macro-economic indicators that are or will } \\
\text { happen }\end{array}$ \\
\hline & & $\begin{array}{l}\text { Said (2011); Said and Grassa (2013); Awaludin and Masih } \\
\text { (2015) }\end{array}$ \\
\hline \multirow{6}{*}{$\frac{\text { 은 }}{\frac{0}{2}}$} & \multirow{2}{*}{$\begin{array}{l}\text { Reputation/ company } \\
\text { size }\end{array}$} & $\begin{array}{l}\text { Reputation / image of the company or company size as } \\
\text { seen from the total assets owned by the company }\end{array}$ \\
\hline & & $\begin{array}{l}\text { Said and Grassa (2013); Zakaria et al. (2013); Shahar et } \\
\text { al. (2014) }\end{array}$ \\
\hline & \multirow{2}{*}{$\begin{array}{l}\text { Amount of profit } \\
\text { sharing/margin/fee }\end{array}$} & $\begin{array}{l}\text { The amount of the profit sharing ratio / fee / service } \\
\text { agreed with the investors in sukuk prospectus }\end{array}$ \\
\hline & & Abdo (2014); Paltrinieri et al. (2015) \\
\hline & \multirow[t]{2}{*}{ Managingmismatch } & $\begin{array}{l}\text { Management of mismatch that occurs between the } \\
\text { average term of the financing DPK / existing projects }\end{array}$ \\
\hline & & Jobst et al. (2008); Paltrinieri et al. (2015) \\
\hline \multirow{5}{*}{ 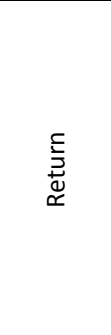 } & \multirow{2}{*}{$\begin{array}{l}\text { The expectations of } \\
\text { investor }\end{array}$} & $\begin{array}{l}\text { Expectations related to expectations of return desired by } \\
\text { investors }\end{array}$ \\
\hline & & BAPEPAM-LK (2009); Awaludin and Masih (2015) \\
\hline & \multirow{2}{*}{ Benchmark market } & $\begin{array}{l}\text { Consideration in comparing the return sukuk that exist in } \\
\text { the local sukuk market }\end{array}$ \\
\hline & & $\begin{array}{l}\text { Tariq and Dar (2007); Zaheer and Wijnbergen (2013); } \\
\text { Shahar et al. (2014); Awaludin and Masih (2015) }\end{array}$ \\
\hline & $\begin{array}{l}\text { Type/ asset } \\
\text { performance }\end{array}$ & $\begin{array}{l}\text { Choice of type of asset or asset performance is the } \\
\text { source of income in the issuance of sukuk }\end{array}$ \\
\hline
\end{tabular}




\begin{tabular}{|c|c|c|}
\hline & (financing project) & $\begin{array}{l}\text { Jobst et al. (2008); Usmani (2007); Rezaei (2013); Abdo } \\
\text { (2014); Shahar et al. (2014) }\end{array}$ \\
\hline \multirow{6}{*}{ 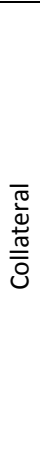 } & \multirow{2}{*}{$\begin{array}{l}\text { Contract and the } \\
\text { structure of sukuk }\end{array}$} & $\begin{array}{l}\text { Option contract and the structure / scheme on sukuk } \\
\text { issued }\end{array}$ \\
\hline & & $\begin{array}{l}\text { Tariq and Dar (2007); Zaheer and Wijnbergen (2013); } \\
\text { Abdo (2014) }\end{array}$ \\
\hline & \multirow[b]{2}{*}{ Syari'ah compliance } & $\begin{array}{l}\text { Companies pay attention to compliance with Islamic } \\
\text { principles (sharia compliance) on guarantees given }\end{array}$ \\
\hline & & $\begin{array}{l}\text { Tariq and Dar (2007); Jobst et al. (2008); Elshazly and } \\
\text { Tripathy (2013); Said and Grassa (2013); Zaheer and } \\
\text { Wijnbergen (2013); Abdo (2014); POJK (2015) }\end{array}$ \\
\hline & \multirow[t]{2}{*}{ Business model } & $\begin{array}{l}\text { Consideration portfolio / business segmentation in TPF } \\
\text { source and financing sources that exist in the company }\end{array}$ \\
\hline & & Abdo (2014) \\
\hline \multirow{6}{*}{ 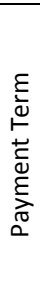 } & \multirow{2}{*}{$\begin{array}{l}\text { Preferences of } \\
\text { investors/ market }\end{array}$} & $\begin{array}{l}\text { Preferences term investor or predominance in the } \\
\text { market or under the provisions of the applicable }\end{array}$ \\
\hline & & Jobst et al. (2008); Oh et al. (2009) \\
\hline & \multirow{2}{*}{ Company liquidity } & The ability of the liquidity-related companies cash flow \\
\hline & & Zaheer and Wijnbergen (2013); Abdo (2014) \\
\hline & \multirow{2}{*}{ Tenor sukuk } & The length of time the issuance of sukuk \\
\hline & & Diaw et al. (2013) \\
\hline
\end{tabular}

\section{Appendix 3.}

\section{Processing Results Pairwase Comparison on Super Decision Software}

\begin{tabular}{|c|c|c|c|c|c|c|c|c|}
\hline \multirow{2}{*}{$\begin{array}{l}\text { Node and } \\
\text { Cluster }\end{array}$} & \multicolumn{2}{|c|}{ Practitioner B1 } & \multicolumn{2}{|c|}{ Practitioner B2 } & \multicolumn{2}{|c|}{ Practioners B3 } & \multicolumn{2}{|c|}{ All Respondents } \\
\hline & $\begin{array}{c}\text { Normalized } \\
\text { By Cluster }\end{array}$ & Limiting & $\begin{array}{c}\text { Normalized } \\
\text { by Cluster }\end{array}$ & Limiting & $\begin{array}{c}\text { Normalized } \\
\text { by Cluster }\end{array}$ & Limiting & $\begin{array}{c}\text { Normalized } \\
\text { by Cluster }\end{array}$ & Limiting \\
\hline 1.1 Management & 0.26107 & 0.040164 & 0.18966 & 0.029179 & 0.31335 & 0.048207 & 0.24133 & 0.037128 \\
\hline 1.2 Finance & 0.30164 & 0.046406 & 0.37395 & 0.05753 & 0.20966 & 0.032256 & 0.28801 & 0.04431 \\
\hline 1.3 Regulation & 0.18133 & 0.027897 & 0.14537 & 0.022364 & 0.24005 & 0.03693 & 0.16789 & 0.025829 \\
\hline 1.4 Investor & 0.25596 & 0.039379 & 0.29102 & 0.044773 & 0.23694 & 0.036453 & 0.30277 & 0.04658 \\
\hline $\begin{array}{l}\text { 1.1.1 Averse selection/ } \\
\text { amount the cost of fund }\end{array}$ & 0.34568 & 0.026826 & 0.33383 & 0.02444 & 0.41105 & 0.033222 & 0.41648 & 0.031815 \\
\hline $\begin{array}{l}\text { 1.1.2 Financial } \\
\text { performance }\end{array}$ & 0.36039 & 0.027968 & 0.33612 & 0.024607 & 0.29447 & 0.0238 & 0.34638 & 0.02646 \\
\hline $\begin{array}{l}\text { 1.1.3 Human resource } \\
\text { knowledge }\end{array}$ & 0.29393 & 0.02281 & 0.33005 & 0.024163 & 0.29447 & 0.0238 & 0.23714 & 0.018115 \\
\hline $\begin{array}{l}\text { 1.2.1 Profitability } \\
\text { condition }\end{array}$ & 0.3873 & 0.031023 & 0.29013 & 0.024531 & 0.43025 & 0.032028 & 0.34738 & 0.027534 \\
\hline 1.2.2 Liquidity condition & 0.33057 & 0.026479 & 0.39395 & 0.033309 & 0.31202 & 0.023227 & 0.33572 & 0.02661 \\
\hline 1.2.3 Capital condition & 0.28213 & 0.022599 & 0.31592 & 0.026711 & 0.25773 & 0.019186 & 0.31691 & 0.025119 \\
\hline $\begin{array}{l}\text { 1.3.1 Underlying asset/ } \\
\text { Income source }\end{array}$ & 0.27381 & 0.019905 & 0.22181 & 0.015634 & 0.27273 & 0.020812 & 0.23669 & 0.017011 \\
\hline $\begin{array}{l}\text { 1.3.2 Accountability and } \\
\text { legalization of } \\
\text { documents }\end{array}$ & 0.38229 & 0.027791 & 0.33716 & 0.023764 & 0.41742 & 0.031854 & 0.35828 & 0.02575 \\
\hline
\end{tabular}




\begin{tabular}{|c|c|c|c|c|c|c|c|c|}
\hline $\begin{array}{l}\text { 1.3.3 The results of using } \\
\text { the sukuk funds }\end{array}$ & 0.34391 & 0.025001 & 0.44103 & 0.031085 & 0.30985 & 0.023645 & 0.40503 & 0.02911 \\
\hline $\begin{array}{l}\text { 1.4.1 Invesment rating } \\
\text { company }\end{array}$ & 0.33047 & 0.025542 & 0.38521 & 0.030604 & 0.43293 & 0.032955 & 0.38877 & 0.031168 \\
\hline 1.4.2 Yield offered & 0.38926 & 0.030086 & 0.32804 & 0.026062 & 0.28501 & 0.021695 & 0.31187 & 0.025003 \\
\hline $\begin{array}{l}\text { 1.4.3 Tradibility/ } \\
\text { liquidity in the } \\
\text { secondary market }\end{array}$ & 0.28027 & 0.021662 & 0.28675 & 0.022782 & 0.28205 & 0.02147 & 0.29935 & 0.023999 \\
\hline 2.1 Emission values & 0.25403 & 0.039081 & 0.22452 & 0.034542 & 0.19441 & 0.02991 & 0.25054 & 0.038544 \\
\hline 2.2 Period & 0.2943 & 0.045277 & 0.1835 & 0.028231 & 0.18579 & 0.028583 & 0.22155 & 0.034085 \\
\hline 2.3 Return & 0.26332 & 0.04051 & 0.22913 & 0.035251 & 0.23952 & 0.03685 & 0.26381 & 0.040586 \\
\hline 2.4 Collateral & 0.11614 & 0.017868 & 0.17874 & 0.027499 & 0.20421 & 0.031417 & 0.1343 & 0.020662 \\
\hline 2.5 Payment term & 0.07222 & 0.01111 & 0.1841 & 0.028323 & 0.17606 & 0.027087 & 0.1298 & 0.019969 \\
\hline $\begin{array}{l}\text { 2.1.1 Additional fund } \\
\text { needs }\end{array}$ & 0.28557 & 0.022956 & 0.26622 & 0.020897 & 0.27698 & 0.021207 & 0.25717 & 0.020615 \\
\hline $\begin{array}{l}\text { 2.1.2 Rentability of } \\
\text { company }\end{array}$ & 0.32118 & 0.025818 & 0.30718 & 0.024112 & 0.40731 & 0.031186 & 0.35252 & 0.028259 \\
\hline $\begin{array}{l}\text { 2.1.3 Macroeconomic } \\
\text { condition }\end{array}$ & 0.39325 & 0.031612 & 0.4266 & 0.033486 & 0.31571 & 0.024173 & 0.39031 & 0.031288 \\
\hline $\begin{array}{l}\text { 2.2.1 Reputation/ } \\
\text { company size }\end{array}$ & 0.31718 & 0.026316 & 0.36061 & 0.027358 & 0.34043 & 0.025877 & 0.33182 & 0.025983 \\
\hline $\begin{array}{l}\text { 2.2.2 Amount of profit } \\
\text { sharing } / \mathrm{margin} / \text { fee }\end{array}$ & 0.31718 & 0.026316 & 0.29721 & 0.022548 & 0.38606 & 0.029345 & 0.31746 & 0.024859 \\
\hline $\begin{array}{l}\text { 2.2.3 Managing } \\
\text { mismatch }\end{array}$ & 0.36563 & 0.030336 & 0.34218 & 0.02596 & 0.27351 & 0.02079 & 0.35072 & 0.027463 \\
\hline $\begin{array}{l}\text { 2.3.1 Expectations of } \\
\text { investors }\end{array}$ & 0.34617 & 0.028033 & 0.32032 & 0.025238 & 0.36155 & 0.028727 & 0.36359 & 0.029456 \\
\hline 2.3.2 Benchmark market & 0.35769 & 0.028966 & 0.37899 & 0.029861 & 0.36155 & 0.028727 & 0.35678 & 0.028904 \\
\hline $\begin{array}{l}\text { 2.3.3 Type/ asset } \\
\text { performance (financing } \\
\text { project) }\end{array}$ & 0.29614 & 0.023982 & 0.30069 & 0.023691 & 0.27691 & 0.022002 & 0.27963 & 0.022654 \\
\hline $\begin{array}{l}\text { 2.4.1 Contract and } \\
\text { structure of sukuk }\end{array}$ & 0.29372 & 0.021015 & 0.37747 & 0.028522 & 0.41287 & 0.031871 & 0.4012 & 0.029172 \\
\hline $\begin{array}{l}\text { 2.4.2 Syari'ah } \\
\text { compliance }\end{array}$ & 0.3187 & 0.022802 & 0.3638 & 0.027489 & 0.2824 & 0.021799 & 0.31185 & 0.022675 \\
\hline 2.4.3 Business model & 0.38758 & 0.02773 & 0.25873 & 0.01955 & 0.30473 & 0.023523 & 0.28695 & 0.020865 \\
\hline $\begin{array}{l}\text { 2.5.1 Preferencesof } \\
\text { investor/ market }\end{array}$ & 0.33333 & 0.022911 & 0.30556 & 0.023193 & 0.34593 & 0.026079 & 0.33589 & 0.024326 \\
\hline 2.5.2 Company liquidity & 0.33333 & 0.022911 & 0.36044 & 0.027359 & 0.36964 & 0.027867 & 0.36214 & 0.026227 \\
\hline 2.5.3 Tenor sukuk & 0.33333 & 0.022911 & 0.334 & 0.025352 & 0.28443 & 0.021443 & 0.30198 & 0.02187 \\
\hline
\end{tabular}

